\title{
Mercury Speciation in Lake Maracaibo, Venezuela, Using Reversed Phase HPLC and ICP-MS
}

\author{
Marinela N. Colina ${ }^{\mathrm{a} *}$, P.H.E. Gardiner ${ }^{\mathrm{b}}$, Zulay Rivas ${ }^{\mathrm{c} * *}$, and Federico Troncone ${ }^{\mathrm{c} * * *}$ \\ ${ }^{a}$ Universidad del Zulia, Facultad Experimental de Ciencias, \\ Laboratorio de Química Ambiental Maracaibo 4011, Zulia, Venezuela \\ b Sheffield Hallam University, Sheffield, S1WB, ,U.K. \\ c Instituto para la Conservación del Lago de Maracaibo (ICLAM), \\ Km1, Carretera Via Perijá, Sector Plaza de las Banderas, Maracaibo, Venezuela
}

\section{INTRODUCTION}

Uncontrolled industrial, agricultural, and domestic discharges into Lake Maracaibo, the largest lake in South America, have resulted in elevated levels of both organic and inorganic pollutants (1). Of the inorganic pollutants, mercury is of great concern because of its potential toxicity and impact on humans, as well as aquatic and other wildlife $(2,3)$. Discharge from a nearby chloralkali plant is the major source of this element. With a surface area of $13,010 \mathrm{~km}^{2}$, the lake undoubtedly plays an important role in both the local and global biogeochemical cycle of mercury. Dissipation of volatile mercury species into the atmosphere is the major pathway by which surface waters lose the element $(4,5)$. At depths of $20 \mathrm{~m}$ or more. retention on sediments and dissolved organic matter, as well as uptake by biological systems account for a large portion of the metal remaining in the water body (6).

Dissolved gaseous mercury (DGM) mainly made up of elemental mercury ( $\mathrm{HgO})$ is formed when $\mathrm{Hg}$ (II) is reduced to Hg either biologically $(6,7)$ or photochemically $(8,9)$. $\mathrm{Hg} 0$ thus produced is volatilized into the atmosphere. Biotic or abiotic methylation of $\mathrm{Hg}$ (II) can occur to form the methylmercury species, $\mathrm{CH}_{3} \mathrm{Hg}^{+}$, and dimethylmercury, $\left(\mathrm{CH}_{3}\right)_{2} \mathrm{Hg}$. These methylated forms readily bioaccumulate in fatty tissue, par-

\footnotetext{
*Corresponding author. E-mail: colinamarinela@gmail.com Tel.: 00584140682977 Fax: 00582617597794

**E-mail: info@iclam.gov.ve
}

\begin{abstract}
The objective of this study was to determine and establish for the first time the distribution of mercury species in a tropical lake in order to understand the nature and factors that influence its biogeochemical cycle. Samples of water, sediments, mussels, and fish muscle tissue collected from Lake Maracaibo were analyzed using a method based on reversed phase high performance liquid chromatography (RP-HPLC) and inductively coupled plasma mass spectrometry (ICP-MS) for the separation and determination of mercury species.

The effect of physicochemical parameters such as $\mathrm{pH}$, salinity, redox potential, etc., and the nutrients $\mathrm{N}, \mathrm{P}$, and $\mathrm{S}$ in determining the chemical speciation of these elements were evaluated. The determination of methylmercury and inorganic mercury was perfomed using RP-HPLC and detection by ICP-MS. The species were found in the different environmental samples obtained from Lake Maracaibo.
\end{abstract}

ticularly in the brain where the devasting effects of the metal are felt (10). In order to assess the environmental impact of mercury, it is essential to identify the different chemical forms and any conditions that may influence their formation. A study using in situ incubation experiments in the Gulf of Mexico found that sunlight, the presence of $\mathrm{Hg}$ (II), and dissolved organic carbon (DOC) are all factors that influence the formation of DGM in shallow coastal waters (11). Recently, sunlight and Fe(III)- induced photochemical reactions have been found to produce DGM (12). Furthermore, diurnal patterns have been established in the formation of dissolved gaseous mercury (13); others $(14,15)$ have been linked to the daily variation in concentrations to mercury oxidase activity in the microorganisms. Reactions leading to the oxidation of elemental mercury in the presence of chloride and sunlight can cause the reduction of organic-free radicals which are involved in the chemical mechanisms leading to DMG loss $(11,12)$. In practice, volatilization of DGM from the water's surface could be due to increased turbulence, warm temperatures, and the nature of the air:water interface (11).

In natural soils and sediments, the predominant mercury species are $\mathrm{Hg}^{2+}$ and $\mathrm{CH}_{3} \mathrm{Hg}^{+}$. The latter is formed in biologically mediated reactions in anoxic sediments in which sulphate-reducing bacteria play a key role $(6,16-18)$. In any ecosystem, such as Lake Maracaibo, the amount of circulating methylmercury is determined by the net balance between methylation and demethylation of the mercury species. Whereas considerable attention has been focused on the methylation processes, relatively little research has been done on the latter. Demethylation of methylmercury has been shown to occur abiotically via photochemical processes (19) or in reactions with sulphides in which dimethylmercury and mercury sulphide are produced. Biotically, the proposed mechanisms involve metabolic pathways in which oxidative demethylation is dominant (19). 
The objective of this study was to determine and establish for the first time the distribution of mercury species in a tropical lake in order to understand the nature and factors that influence its biogeochemical cycle. Samples of water, sediments, mussels, and fish muscle tissue collected from Lake Maracaibo were analyzed using a method based on reversed phase high performance liquid chromatography (RP-HPLC) and inductively coupled plasma mass spectrometry (ICP-MS) for the separation and determination of mercury species. The effects of physicochemical parameters such as $\mathrm{pH}$, salinity, redox potential, etc., and nutrients in determining the chemical speciation of mercury were evaluated.

\section{EXPERIMENTAL}

\section{Instrumentation}

The HPLC system (isocratic conditions) used for these studies consisted of a DIONEX GPM 2 (Dionex Corporation, Sunnyvale, CA, USA) gradient pump, equipped with a Rheodyne $^{\circledR}$ Model 7125 injection valve with a $50-\mu \mathrm{L}$ sample loop. Also used was a $\mathrm{C}_{18}$ reversed phase column (150 mm x $3.9 \mathrm{~mm}, 4 \mu \mathrm{m})$ consisting of dimethyl-octadecylsilylbonded amorphous silica (Waters HPLC column, Milford, MA, USA), with a helium pressure of $10 \mathrm{psi}$ and a flow rate of $1.0 \mathrm{~mL} \mathrm{~min}$.

For the determination of mercury, the most abundant ${ }^{202} \mathrm{Hg}$ isotope was used. A Hewlett-Packard ${ }^{\circledR}$ 4500 ICP-MS (Hewlett Packard Company, Palo Alto, CA, USA) was used as the detector. The mobile phase was connected directly into the nebulizer and did not require ICP-MS pumps. Table I lists the ICPMS operating conditions.

The LC conditions standardized during the study are listed on page 6 in Table V. The water samples were filtered through a $0.2 \mu \mathrm{m}$ Millipore $\AA$ filter before injection into the HPLC system for the determination of the mercury species.

\section{Sampling}

The study area of Lake Maracaibo was between Latitude 9032' and 1100' North and Longitude 71001' - 72001' West (Figure 1). The samples were taken from 17 sampling points during November 1998 and March 1999. Three samples of $1 \mathrm{~L}$ of water (at one meter depth) were taken at 15 sites and $1 \mathrm{Kg}$ of sediment sample each was taken from 13 sampling sites. All in situ parameters were measured using the R/V Bergantin system obtained from The Institute for the Conservation of Lake Maracaibo, Venezuela (ICLAM). Physicochemical parameters including temperature, $\mathrm{pH}$, conductivity, salinity, dissolved oxygen, and redox potential were measured with a Hydrolab Surveyor II (obtained from Campell Scientific Canada Corporation, Edmonton, Alberta T5M 1W7, Canada) at different depths of the lake. Only the parameters at $1.0 \mathrm{~m}$ depth and those near to the sediment surface were considered for this study (Tables II and III). Before sampling, all plastic bottles were carefully acid-washed and then rinsed with deionized water. The water samples were obtained by using a diaphragm pump (JABSCO, PARMAX4, model 30620-00-12),

TABLE I ICP-MS Operating Conditions

\begin{tabular}{lr}
\multicolumn{1}{c}{ Conditions for Hg Speciation } \\
\hline Rf Power & \multicolumn{1}{c}{$1200 \mathrm{~W}$} \\
Torch & Fassel Torch \\
Spray Chamber & Cyclonic \\
Nebulizer & Babington \\
Coolant Gas Flow & $10 \mathrm{~L} \mathrm{~min}^{-1}$ \\
Sample Introduction & HPLC gradi- \\
& ent pump \\
Carrier Gas Flow & $1.25 \mathrm{~L} \mathrm{~min}^{-1}$ \\
Sample Depth & $6.0 \mathrm{~mm}^{-}$ \\
Pump Speed & $0.30 \mathrm{rps}$ \\
Acquisition & 2-sec using \\
& time-resolved analysis \\
\hline
\end{tabular}

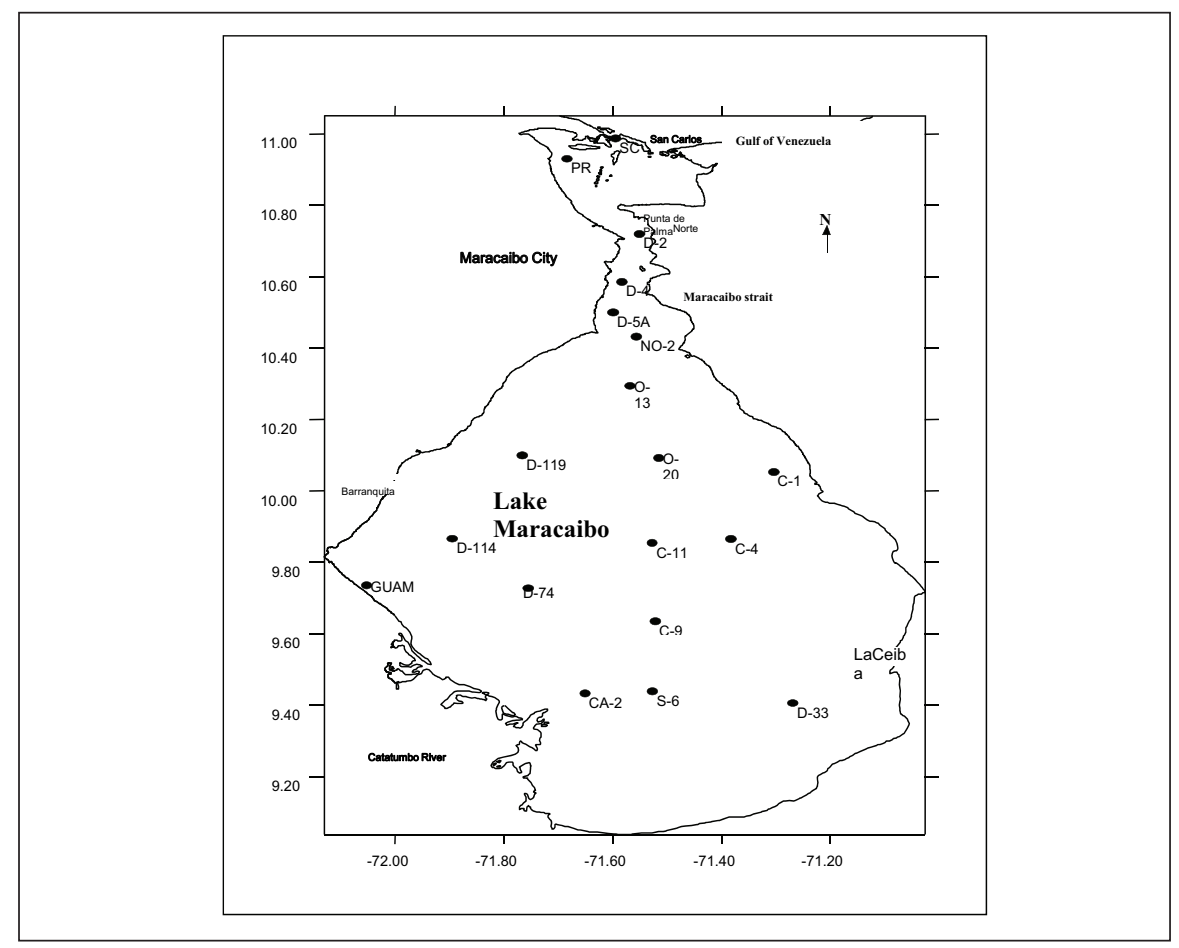

Fig. 1. Lake Maracaibo and the sampling sites. 


\section{Atomic Spectroscopy \\ 1 Vol. 32(1), Jan./Feb. 2011}

TABLE II

Parameters Measured in situ for Samples of Water Taken at Depth of $1 \mathrm{~m}$

\begin{tabular}{|c|c|c|c|c|c|}
\hline Site & $\begin{array}{l}\text { Temp. } \\
\left({ }^{\circ} \mathrm{C}\right)\end{array}$ & $\mathrm{pH}$ & $\begin{array}{l}\text { Conduc- } \\
\text { tivity } \\
(\mu \mathrm{S})\end{array}$ & $\begin{array}{c}\text { Dissolved } \\
\text { Oxygen } \\
\left(\mathrm{mg} \mathrm{L}^{-1}\right)\end{array}$ & $\begin{array}{l}\text { Salinity } \\
\left(\mathrm{g} \mathrm{L}^{-1}\right)\end{array}$ \\
\hline D-114 & 29.95 & 7.54 & 7.19 & 6.70 & 3.9 \\
\hline O-13 & 30.67 & 7.78 & 7.26 & 7.16 & 3.9 \\
\hline O-20 & 30.92 & 8.01 & 7.62 & 8.05 & 4.1 \\
\hline D-2 & 29.72 & 7.97 & 7.66 & 6.26 & 4.2 \\
\hline D-33 & 29.63 & 7.91 & 6.19 & 7.43 & 3.3 \\
\hline PR & 30.02 & 8.25 & 8.02 & 7.01 & 4.4 \\
\hline SC & 29.53 & 8.18 & 8.89 & 7.18 & 4.9 \\
\hline D-4 & 29.73 & 7.81 & 7.09 & 6.03 & 3.8 \\
\hline D-5a & 29.94 & 7.82 & 7.03 & 5.92 & 3.8 \\
\hline C-9 & 29.78 & 7.30 & 8.18 & 4.88 & 4.5 \\
\hline C-1 & 31.15 & 8.13 & 7.09 & 7.30 & 3.8 \\
\hline C-11 & 29.85 & 7.43 & 7.73 & 5.37 & 4.2 \\
\hline C-1 & 31.15 & 8.13 & 7.09 & 7.30 & 3.8 \\
\hline NO-2 & 27.82 & 7.82 & 7.03 & 5.92 & 3.8 \\
\hline CA-2 & 29.28 & 7.44 & 6.00 & 6.10 & 3.2 \\
\hline S-6 & 28.89 & 8.05 & 7.14 & 6.56 & 3.9 \\
\hline D-119 & 29.36 & 8.44 & 6.77 & 7.52 & 3.6 \\
\hline D-74 & 28.45 & 7.43 & 7.41 & 4.90 & 4.0 \\
\hline
\end{tabular}

The sediment samples were taken using an Eckman dredge. The sediments were homogenized and kept in plastic bags at $-4{ }^{\circ} \mathrm{C}$ during sampling, then transferred to a 50-mL plastic bottle and frozen to $-20{ }^{\circ} \mathrm{C}$. The sediments were covered and maintained in the dark until analysis. Before lyophilization, the sediments were kept frozen to avoid losses during defrosting.

\section{Standard Solutions and Reagents}

The inorganic mercury solution was prepared from a stock solution of $1000 \mathrm{mg} \mathrm{L}^{-1} \mathrm{Hg}$ ICP Aristar standard in $2 \% \mathrm{HNO}_{3}$ (Merck, Poole, Dorset, U.K.). The stock solution of $1000 \mathrm{mg} \mathrm{L}^{-1}$ of the methyl mercury chloride (Riedel-de-Haen, Seelze, Germany) was made by dissolving $0.125 \mathrm{~g}$ in $10 \mathrm{~mL}$ of $10 \% \mathrm{HNO}_{3}$ (v/v).
TABLE III

Parameters Measured in situ for Maximum Depth (Zone Nearest to Surface Sediments)

\begin{tabular}{lllcccc}
\hline Site & Temp & $\mathrm{pH}$ & $\begin{array}{c}\text { Conduc- } \\
\text { tivity } \\
(\mu \mathrm{S})\end{array}$ & $\begin{array}{c}\text { Dissolved } \\
\text { Oxygen } \\
\left(\mathrm{mg} \mathrm{L}^{-1}\right)\end{array}$ & $\begin{array}{c}\text { Salinity } \\
\left(\mathrm{g} \mathrm{L}^{-1}\right)\end{array}$ & $\begin{array}{c}\text { Depth } \\
(\mathrm{m})\end{array}$ \\
\hline SC & 27.33 & 8.15 & 30.9 & 6.25 & 19.2 & 9.9 \\
D-2 & 28.15 & 7.73 & 15.8 & 3.06 & 9.2 & 10.8 \\
D-4 & 28.54 & 7.73 & 7.31 & 4.9 & 4.0 & 14 \\
NO-2 & 29.21 & 8.46 & 6.87 & 6.28 & 3.7 & 14.7 \\
O-13 & 28.91 & 7.61 & 6.56 & 4.97 & 3.5 & 15 \\
O-20 & 28.46 & 7.3 & 7.12 & 3.49 & 3.9 & 27.1 \\
C-9 & 28.81 & 7.17 & 9.74 & 0.05 & 5.4 & 28 \\
CA-2 & 28.64 & 7.79 & 6.72 & 3.45 & 3.6 & 25.2 \\
D-33 & 28.46 & 7.08 & 7.47 & 1.90 & 4.1 & 28.7 \\
C-1 & 28.68 & 7.13 & 8.45 & 0.79 & 4.6 & 28.1 \\
PR & 29.74 & 8.27 & 8.19 & 6.80 & 4.5 & 3.2 \\
D-5a & 29.98 & 7.84 & 7.12 & 5.72 & 3.8 & 14.6 \\
C-11 & 30.06 & 6.62 & 14.10 & 0.01 & 8.1 & 27.7 \\
\hline
\end{tabular}

and fish muscle tissue of curvina (Cysnocion acoupa Maracaiboencis) were extracted using two different methods:

(a) For the cold digestion procedure (21), an amount of 1.5-2.0 $\mathrm{g}$ freezedried sample was mixed with $2 \mathrm{~mL}$ of concentrated $\mathrm{HNO}_{3}$ and $1 \mathrm{~mL}$ of $\mathrm{H}_{2} \mathrm{O}_{2}$, left standing for 24 hours at room temperature, then diluted with deionized water to $15-\mathrm{mL}$ solution. The solution $\mathrm{pH}$ was about 1.0.

(a) For the digestion/extraction method, an amount of 1.5-5.0 g of freeze-dried sample was mixed with $10 \mathrm{~mL}$ of water, $5 \mathrm{~mL}$ of $\mathrm{HCl}$, and $20 \mathrm{~mL}$ of toluene in a $100-\mathrm{mL}$ conical flask and shaken for $10 \mathrm{~min}$ utes. This mixture was centrifuged at $3000 \mathrm{rpm}$ for 5 minutes. Then, $12 \mathrm{~mL}$ of the extracted organic phase was mixed with $3 \mathrm{~mL}$ of L-cysteine and shaken for 2 minutes. This mixture was centrifuged for 5 minutes and $2 \mathrm{~mL}$ of the aqueous phase taken for the determination of the mercury species. The final pH was about 4 . 
After extraction or digestion, the samples were adjusted to $\mathrm{pH} 6.5$ with $1 \% \mathrm{NaOH}$. The final HPLC conditions used were as follows:

Mobile phase: $0.06 \mathrm{M}$ ammonium acetate, 3\% methanol, $0.1 \%$ 2-mercaptoethanol, 2 mM EDTA, pH 6.5. Column: $\mathrm{C}_{18}$ (Reversed Phase).

The total mercury, nitrogen, phosphorus, and sulphur content was determined by a method previously reported using microwave digestion and ion chromatography detection (22).

\section{RESULTS AND DISCUSSION}

\section{Lake Maracaibo System}

This lake is connected to the Gulf of Venezuela via the Strait of Maracaibo and the Bay El Tablazo. The sampling points in the three zones were as follows:

(a) The Gulf of Venezuela (mixing zone with the Caribbean Sea), with sampling points $S C$ and $P R$.

(b) The Strait of Maracaibo (intermediate zone) with sampling points D-2, D-4, D5a, and NO-2.

(c) The rest of the sampling points were from the main zone of the lake.

Although considerable research has been conducted to establish the salient features of the hydrodynamics of Lake Maracaibo, little has been done to quantify the exchange between Lake Maracaibo and the Gulf of Venezuela in characterizing their internal processes and interactions. Furthermore, there have been no attempts to describe the dynamics of the entire system. Figures $2(a, b$, and $c)$ show the variations in salinity found at the different depths during 1999 at three different zones of the Lake Maracaibo system: the estuary, the strait, and the lake itself (SC, D-2, and C-9).

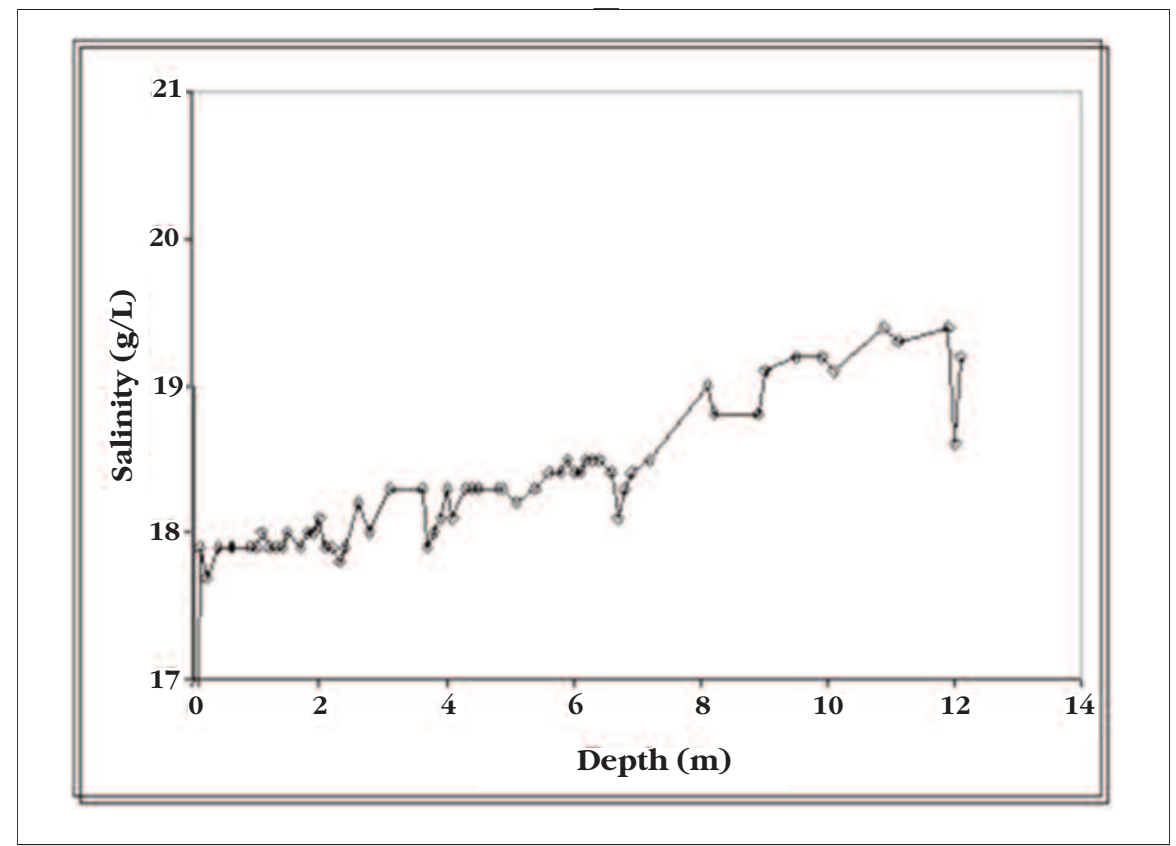

Fig. 2 (a). Point SC: Variations in salinity at Lake Maracaibo Estuary at different depths.

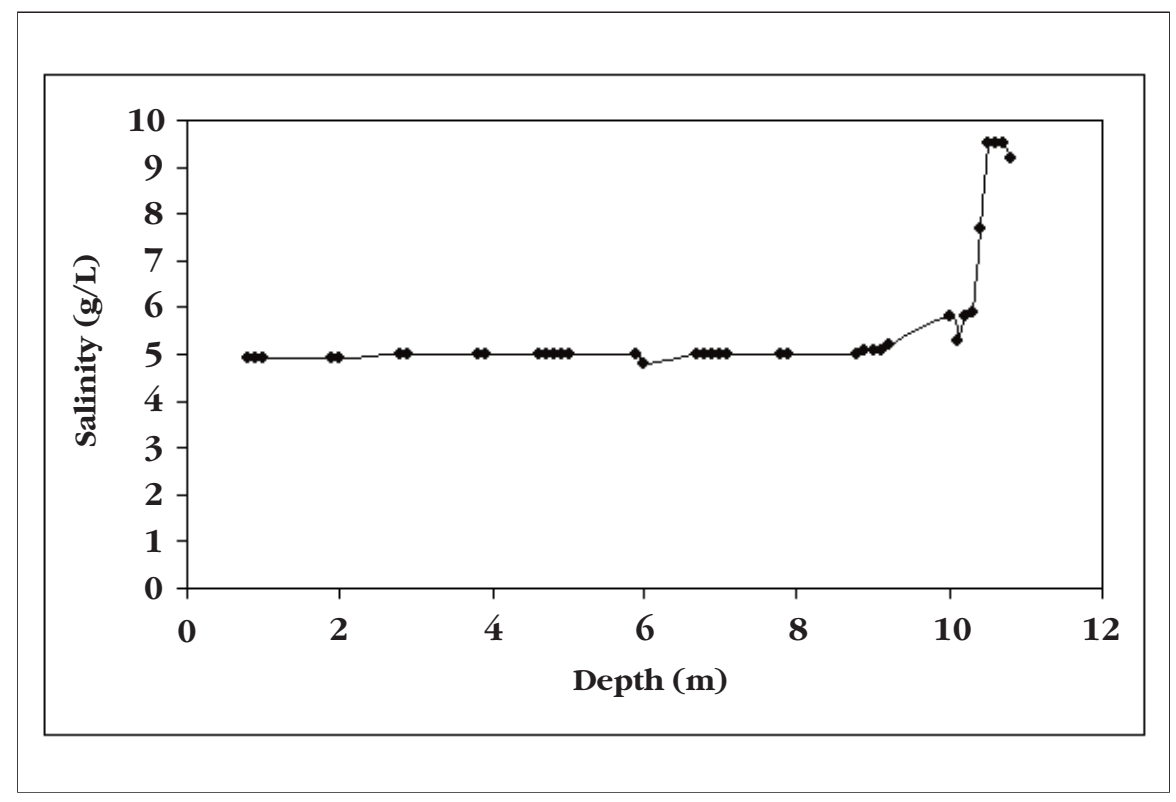

Fig. 2 (b). Point D-2: Variations in salinity at Lake Maracaibo Strait at different depths. 


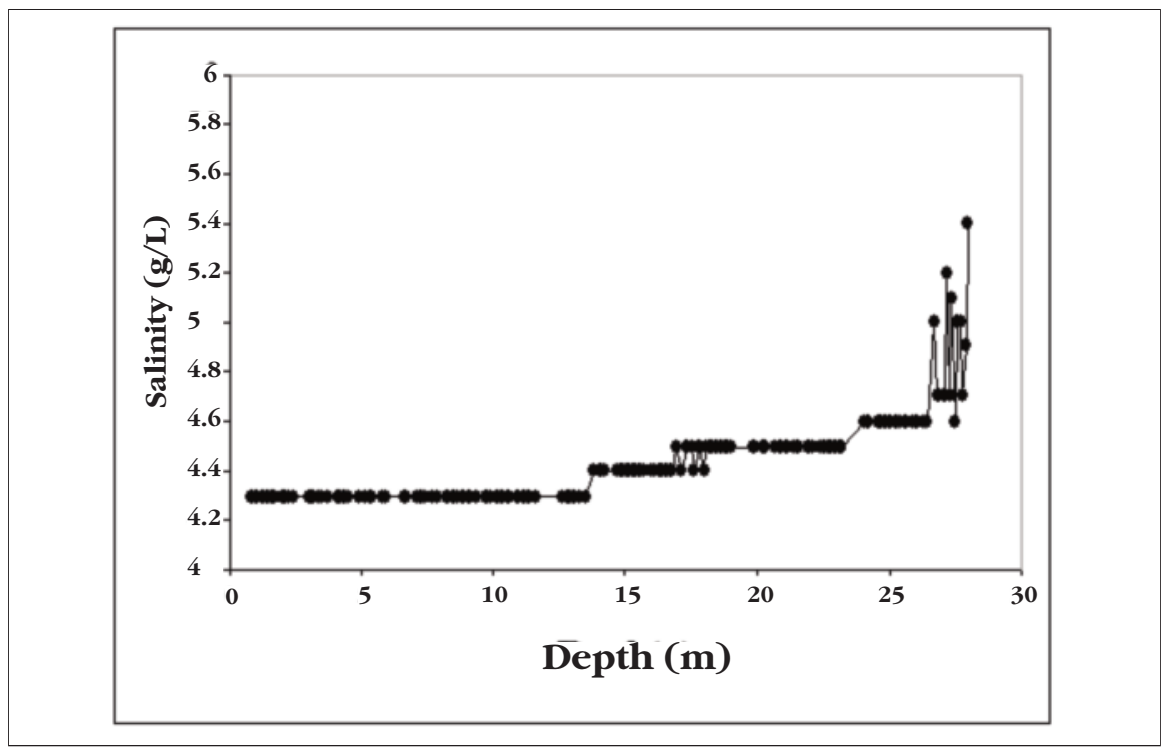

Fig. 2 (c). Point C-9: Variations in salinity at Lake Maracaibo proper at different depths.

TABLE IV

Total Nitrogen, Phosphorus, and Sulfur ( $\left.\mu \mathrm{mol} \mathrm{g} \mathbf{g}^{-1}\right)$ Determined in Sediment Samples From Lake Maracaibo

\begin{tabular}{crrrrrr}
\hline $\begin{array}{c}\text { Sampling } \\
\text { Points }\end{array}$ & $\mathrm{N}$ & $\mathrm{SD}$ & $\mathrm{P}$ & $\mathrm{SD}$ & \multicolumn{1}{c}{$\mathrm{S}$} & \multicolumn{1}{c}{ SD } \\
\hline PR & 3.9 & 0.3 & $<0.03$ & & 320.5 & 12.0 \\
SC & 0.9 & 0.4 & $<0.03$ & & 33.0 & 3.0 \\
D-2 & 3.2 & 0.3 & $<0.03$ & & 287.8 & 39.1 \\
D-4 & 4.8 & 0.3 & $<0.03$ & & 770.3 & 29.0 \\
D5a & 1.7 & 0.1 & 1.2 & 0.1 & 11.7 & 1.20 \\
NO2 & 5.2 & 0.3 & 1.3 & 0.1 & 470.9 & 11.6 \\
O-13 & 2.6 & 0.1 & 9.5 & 0.1 & 1719.2 & 35.4 \\
O-20 & 10.6 & 1.1 & 40.6 & 3.9 & 1947.3 & 40.5 \\
C-1 & 4.2 & 0.4 & 31.1 & 0.3 & 132.8 & 13.4 \\
C-11 & 9.6 & 1.9 & 12.9 & 1.2 & 1248.0 & 27.6 \\
C-9 & 8.1 & 1.5 & 15.0 & 1.0 & 1176.9 & 69.5 \\
CA2 & 0.1 & 0.1 & 27.1 & 1.0 & 1412.3 & 30.6 \\
D-33 & 1.0 & 0.1 & 10.4 & 1.0 & 1975.6 & 91.1 \\
\hline
\end{tabular}

Lake Maracaibo is a stratified lake in which salinity changes with depth. The cone-shaped hypolimnion is defined by higher salinity and lower temperature than the overlying epilimnetic water that circulates at the hypolimnetic layer in a counterclockwise direction (20). Table IV shows the nitrogen
(N), phosphorus (P), and sulfur (S) $\left(\mu \mathrm{mol} \mathrm{g}^{-1}\right)$ total content measured in the sediment samples during this study. The values for total nitrogen content in water and sediments are very high when compared, for example, to a subtropical bay in Oahu, Hawaii, where Stimson and Larned (21) determined the nitro- gen efflux from the sediments. The maximum concentrations of the dissolved nitrogen in positions close to the sediments were in the range of $0.38-0.72 \mu \mathrm{M}$. The concentration in water at the depth of one meter in Lake Maracaibo exceeds this range. However, the concentrations of total phosphorus in Lake Maracaibo were lower (except 0-20 $\mathrm{mmol} \mathrm{g}^{-1}$ ) than those found in other lakes such as Langjon, Flaten, and Gommaren in Sweden where the range of total phosphorus was 36.2 - $62.6 \mu \mathrm{mol} \mathrm{g}{ }^{-1}$ (22). Sediments can accumulate sulfur in the range of $132.8 \mu \mathrm{mol} \mathrm{g} \mathrm{g}^{-1}$ where pyrite is the most common mineral form of sulfur (23). In Lake Maracaibo, the concentration of sulfur during this study was in the range of 11.6 - $1975 \mathrm{~mol} \mathrm{~g}^{-1}$ which could be due to the tidal inflow of salt water from the Caribbean Sea. Another characteristic of the lake is depletion of dissolved oxygen with concentrations of around zero $\mathrm{mg} \mathrm{L}^{-1}$ in the center. In this zone, sulfur occurs as a reducible form of mostly hydrogen sulfate $\left(\mathrm{HS}^{-}\right)$ which can result in the precipitation of metals such as $\mathrm{Hg}, \mathrm{Pb}$, and Se. Lake Maracaibo can be classified as a hyper-eutrophic lake because of the high concentrations of phosphorus.

The calibration curve for the determination of total mercury was $\mathrm{y}=8.0 \times 10^{3} \mathrm{X}+4.3 \times 10^{3}$ and using the cold digestion procedure with a detection limit of $0.05 \mu \mathrm{g} \mathrm{L} \mathrm{L}^{-1} \mathrm{Hg}$. The detection limit for the merury species determination increased despite an increase in the eluent background signal.

Table V shows the optimal chromatographic conditions and mobile phase used to determine inorganic mercury and methylmercury; selenocystine and selenomethionine could also be determined with the method. 
TABLE V

LC Operating Conditions

\begin{tabular}{lll}
\hline LC & Column & Mobile Phase \\
\hline Reversed Phase & $\mathrm{C}_{18}$ & $0.06 \mathrm{M}$ ammonium acetate \\
& & $5 \%$ methanol, $0.1 \%$ \\
& & 2-mercaptoethanol \\
& & pH=6.5 \\
Reversed Phase & $\mathrm{C}_{18}$ & $0.045 \mathrm{M}$ ammonium acetate \\
& & $2.5 \%$ methanol, $0.1 \%$ \\
& & 0.075 -mercaptoethanol \\
& & pH=6.5 \\
Reversed Phase & $\mathrm{C}_{18}$ & $0.06 \mathrm{M}$ ammonium acetate \\
& & $3 \%$ methanol, $0.1 \%$ \\
& & 2 -mercaptothanol \\
& & 2 mM EDTA \\
& & pH=6.5 \\
\hline
\end{tabular}

Calibration Curves:

\begin{tabular}{lll}
$\mathrm{CH}_{3} \mathrm{Hg}^{+}$ & Retention time: $480 \mathrm{sec}$ & $\mathrm{y}=331.2 \mathrm{X}+669.1$ \\
$\mathrm{r}^{2}=0.99933$ & Detection limit: $2.4 \mu \mathrm{g} \mathrm{L}^{-1}$ & \\
$\mathrm{Hg}^{2+}$ & Retention time: $680 \mathrm{sec}$ & $\mathrm{y}=129.7 \mathrm{X}+1127.2$ \\
$\mathrm{r}^{2}=0.99829$ & Detection limit : $4.3 \mu \mathrm{g} \mathrm{L}^{-1}$ & \\
\hline
\end{tabular}

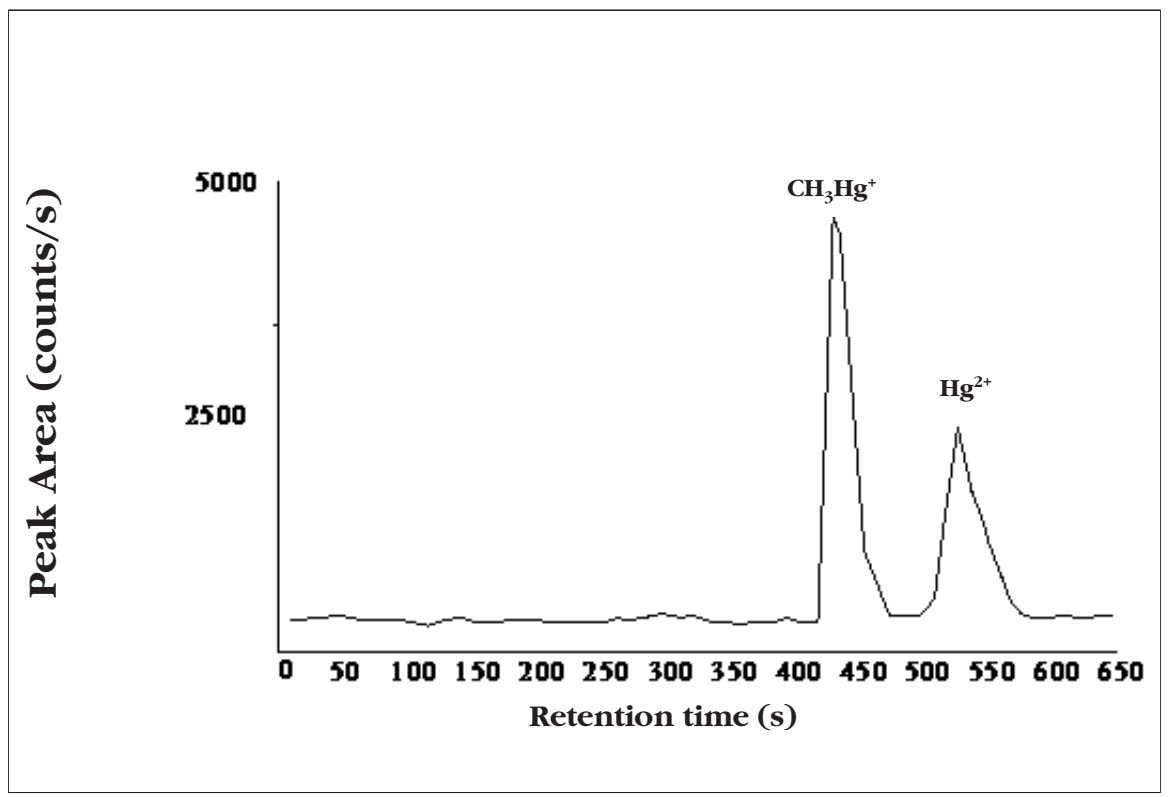

Fig. 3. Chromatogram of a solution of $40 \mathrm{~g} \mathrm{~L}^{-1}$ methyl mercury and $40 \mathrm{~g} \mathrm{~L}^{-1}$ inorganic mercury using the proposed RP HPLC-ICP-MS method.

Figure 3 shows good separation of the mercury species using a $40-\mu \mathrm{g} \mathrm{L}^{-1}$ solution of inorganic mercury and $40 \mu \mathrm{g} \mathrm{L}^{-1}$ methyl mercury in the third mobile phase.
The methodologies were evaluated for methyl mercury, mercury total content, and selenium total content in sediment using Reference Material IAEA 356 and LGC
6137; the results are shown in Tables VI and VII (IAEA = International Atomic Energy Agency; LGC=Labratory of the Government Chemist, Middlesex, UK). There were no statistically significant differences between the total mercury concentrations in the reference materials and the concentrations found for these materials using the proposed method.

\section{RESULTS OF ENVIRONMENTAL MERCURY}

\section{Mercury in Waters}

It is interesting to note that the levels of methyl mercury in waters are usually lower than those of inorganic mercury. This is due to the difficulty of methylation reactions in aqueous phases and easy decomposition by solar UV light (24-25) of organo-mercury compounds. The results obtained for the water samples of Lake Maracaibo ranged between 1.1 to $7.8 \mu \mathrm{g} \mathrm{L}^{-1}$ for total mercury concentration. This is below the detection limit of the determination method developed for mercury species in this study but higher than the recommended drinking water standards $\left(1 \mu \mathrm{g} \mathrm{L}^{-1}\right)$ by the EC (European Community), WHO (World Health Organisation), and TVO-D (German drinking water standards) (25).

\section{Mercury in Sediments}

In sediments and biota, the levels of methyl mercury normally are higher than in the waters because of the accumulative phenomena (26); inorganic mercury and methyl mercury are pre-concentrated in sediments. Figure 4 shows the chromatogram of the mercury species from a sediment sample from the center of Lake Maracaibo. A high peak of methylmercury is shown in the figure which is the most dangerous species. 


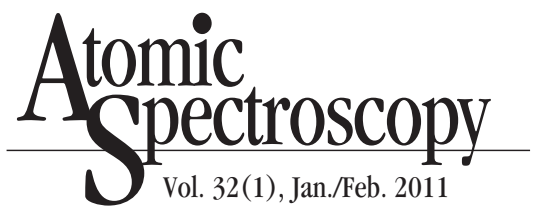

TABLE VI

Comparison of Results Obtained With Reference Material IAEA-356

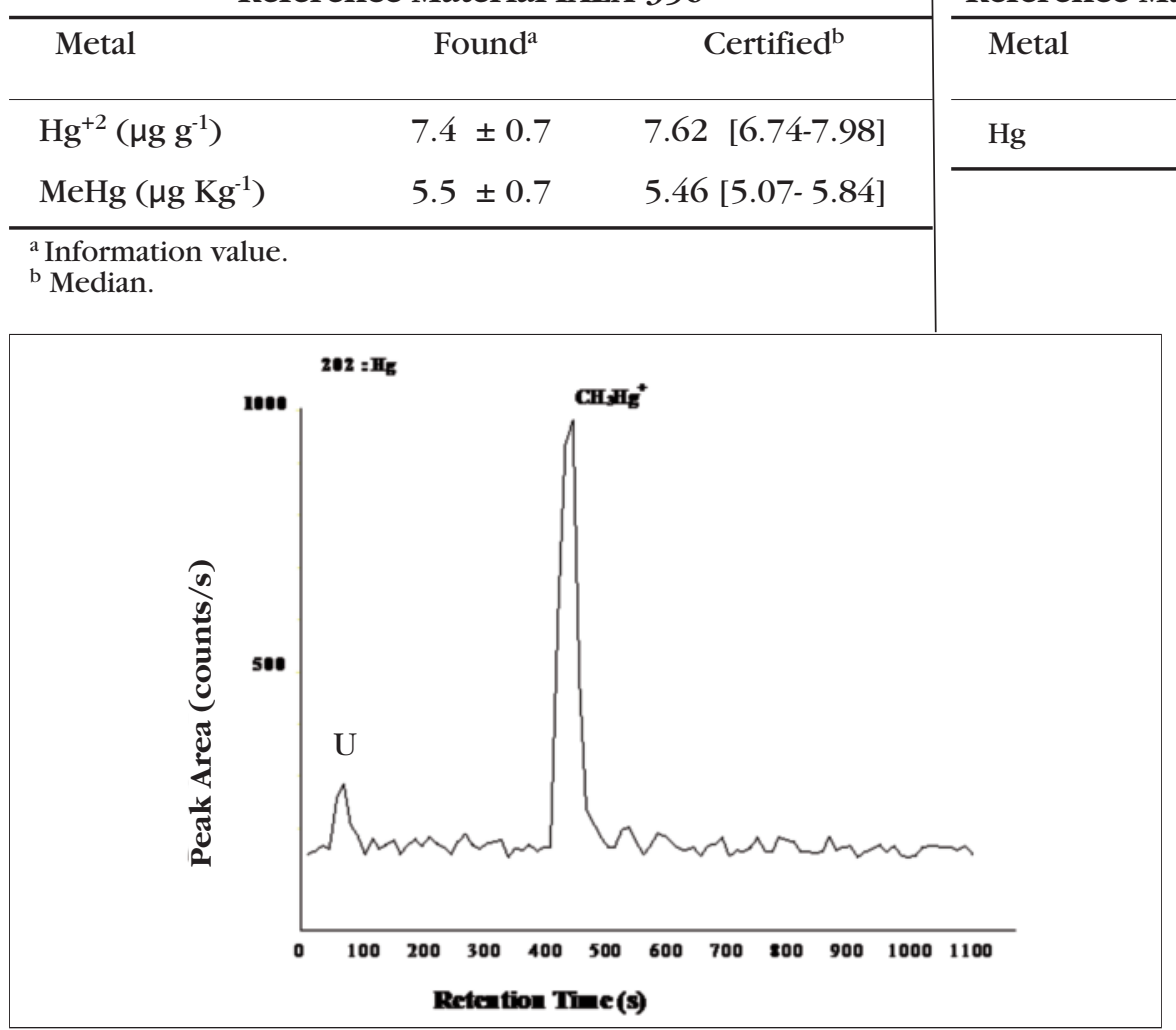

Fig. 4. Chromatogram of a sediment sample from the center of Lake Maracaibo (U: unidentified peak).

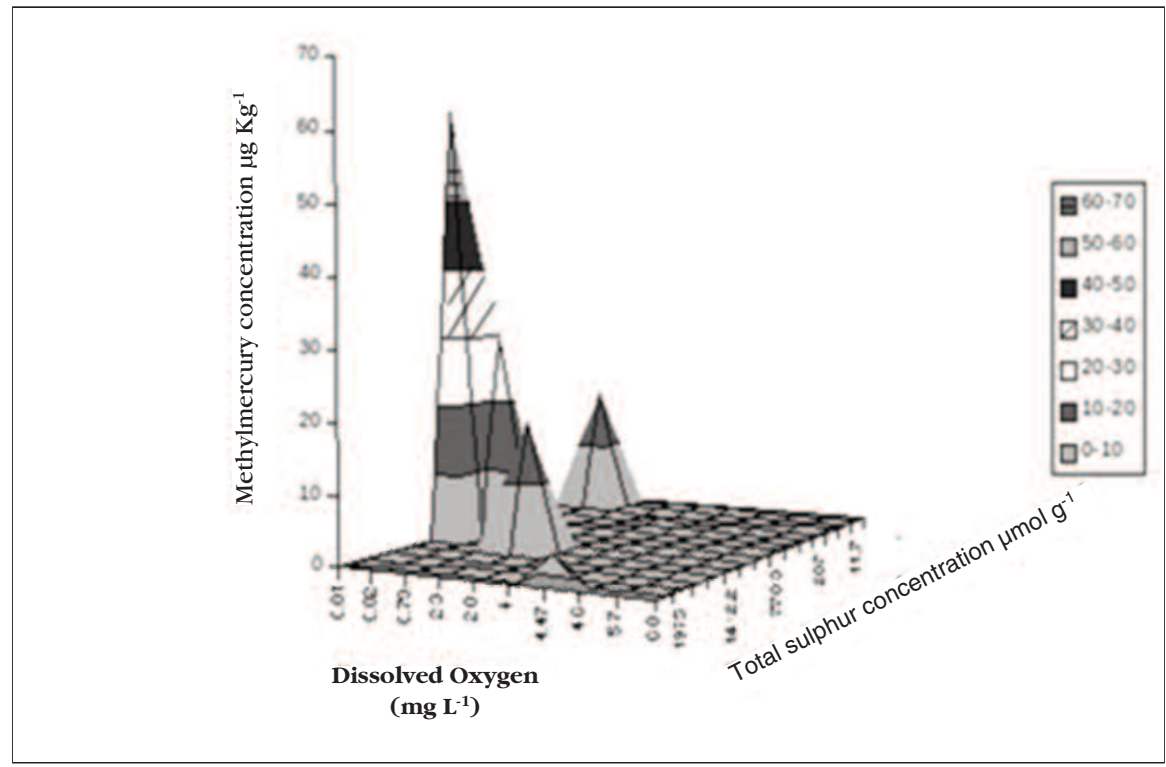

Fig. 5. Variation of the concentration of methylmercury $\left(\mu g \mathrm{Kg}^{-1}\right)$, total sulphur concentration, and dissolved oxygen concentration.
TABLE VII

Comparison of Results Obtained With Reference Material Estuarine Sediment LGC 6137

Certified

$\left(\mu \mathrm{g} \mathrm{g}^{-1}\right)$

$\begin{array}{ll}\left(\mu \mathrm{g} \mathrm{g}^{-1}\right) & \left(\mu \mathrm{g} \mathrm{g}^{-1}\right) \\ 0.38 \pm 0.05 & 0.34 \pm 0.05\end{array}$

There are three systems in Lake Maracaibo that are clearly different. The behavior of the mercury species in the Gulf (PR and SC points) zone corresponds to a mixture of the two species of methyl mercury $\left[18.6-39.7 \mu \mathrm{g} \mathrm{Kg}^{-1}\right]$ and inorganic mercury $[50.2-79.2 \mu \mathrm{g}$ $\mathrm{Kg}^{-1}$ ]. In this zone, the $\mathrm{pH}$ is high, salinity and sulfur concentrations are low, and the dissolved oxygen concentration and redox potential are high. In the Strait of Maracaibo, only inorganic mercury was found [30.4 - 85.5 $\left.\mathrm{g} \mathrm{Kg}^{-1}\right]$. This zone is near a petrochemical complex which had a chlor-alkali plant and the coal is transported over the lake from an open mine.

The multivariant analysis correlations between $\mathrm{Hg}^{2+}$, total mercury, and $\mathrm{MeHg}^{+}$, and the nutrients $\mathrm{N}, \mathrm{P}$, and $\mathrm{S}$, showed no correlations. However, in the main zone of the lake there is a cone in the center which has zero oxygen content and high salinity at the bottom. Figures 5 and 6 show the variation of the methylmercury concentration with the physicochemical parameters and total sulfur concentration. The zone with a high concentration of methylmercury corresponds to a zone with very low concentration of dissolved oxygen, lower $\mathrm{pH}$, negative redox potential, high salinity, and high concentration of sulfur (under reduced conditions). Sites with high concentrations of total sulfur but high dissolved oxygen, or low dissolved oxygen and low total sulfur concentration, have low methyl mercury concentrations. 


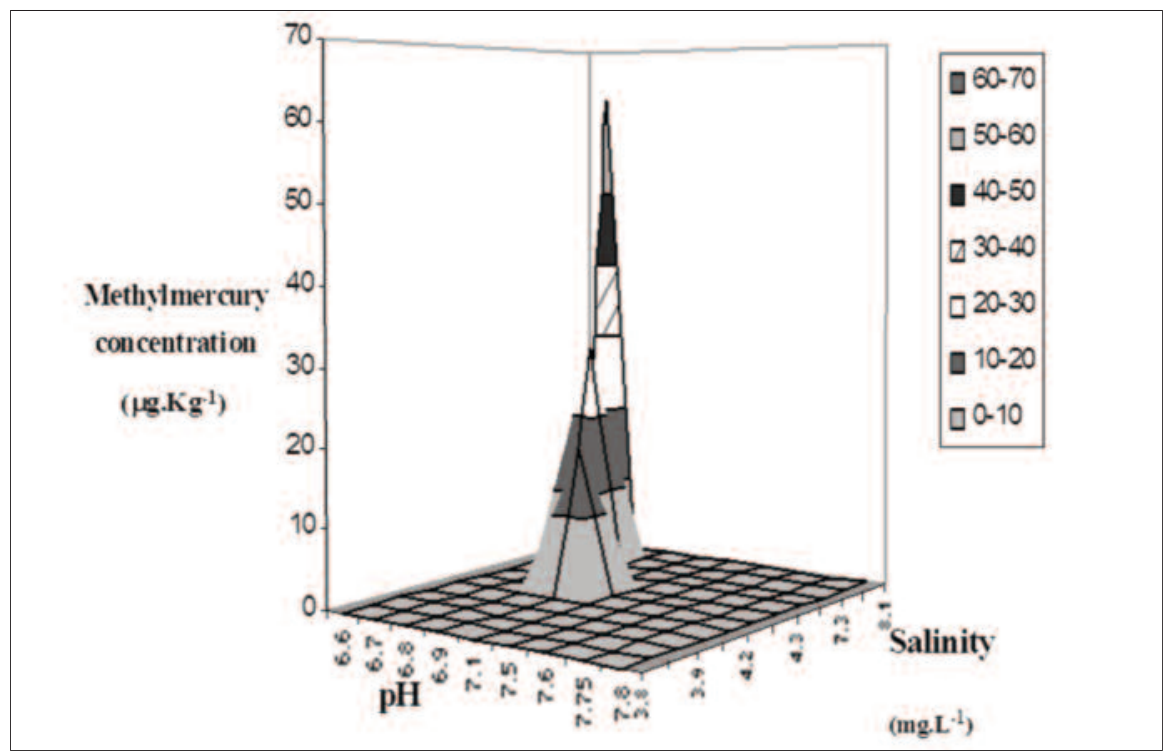

Fig. 6. Variation of the methyl mercury $\left(\mu g \mathrm{Kg}^{-1}\right)$ concentration, $\mathrm{pH}$, and salinity at the surface sediments from the center of the Lake Maracaibo.

Multivariable analysis correlations of the mercury species and the physicochemical parameters showed correlations between $\mathrm{MeHg}^{+}$and salinity $(\mathrm{r}=0.885, \mathrm{n}=13$, $\mathrm{p}<0.0286$ ) and $\mathrm{Hg}^{2+}$ and dissolved oxygen concentrations $(\mathrm{r}=0.6601$, $\mathrm{n}=13, \mathrm{p}<0.0141$ ) in all zones of the lake.

The behavior of $\mathrm{MeHg}^{+}$and sulfur can be explained in terms of coordination chemistry. Binding constants for inorganic ligands show that $\mathrm{MeHg}^{+}$, like $\mathrm{Hg}^{2+}$, is a $\mathrm{B}$ class acceptor $(27,28)$. Methylmercury forms extremely stable complexes with anionic sulfur ligands. Furthermore, sulfide is known to occur in anoxic environments where the rate of oxygen removal is close to or exceeds its rate of supply. In such environments, the residual oxygen is present at low or non-detectable levels. At these levels, sulfate is used by anaerobic bacteria as an electron acceptor, leading to the reduction of sulfate to sulfide. These environments are highly dynamic regions and remarkable variations in the dissolved concentration of metals have been found at the oxic-anoxic boundary in anoxic lakes (29).
The results from Lake Maracaibo showed that the methylmercury concentrations can increase with increasing sulfur concentrations under certain conditions. On the other hand, the correlation between methylmercury and salinity could be an indication because in Lake Maracaibo the salinity increases with depth, with maximum salinity occurring in the center of the Lake. There is also a high concentration of sulfur from sulfate intrusion from the Caribbean Sea.

\section{Mercury Total Content}

The sediments from Lake Maracaibo reveal a total mercury concentration ranging from 126.3 to $277.5 \mu \mathrm{g} \mathrm{Kg}^{-1}$. These concentrations are low when compared with Lake Bjorken (Sweden) which has $11 \mathrm{mg} \mathrm{Kg}^{-1} \mathrm{Hg}$ (30). However, the EC threshold values of total mercury concentration in soil are 1.0-1.5 $\mathrm{mg} \mathrm{Kg}^{-1}$ and $0.3-10.0 \mathrm{mg} \mathrm{Kg}^{-1}$ in the Netherlands (Dutch standards). The general conditions of Lake Maracaibo as a eutrophic lake do not favor the methylation process. Eutrophic lakes have a high productivity and thus a large biomass in which methyl mercury will be diluted. The $\mathrm{pH}$ in eutrophic lakes is usually high, which favors the formation of the volatile dimethylmercury that may escape from the system (31). The high productivity in eutrophic lakes gives rise to large amounts of complexing agents and also to high sedimentation rates. In addition, Lake Maracaibo is a tropical lake which has a high rate of productivity because of its temperature (32). However, Lake Maracaibo is continuously dredged to maintain a shipping channel, and these dredging activities disperse uncovered mercury sediments over large areas and are likely to result in an increase in mercury content in the flora and fauna over a period of time.

\section{Mercury in Fish Muscle and Mussels}

The high affinity of methyl mercury for sulphydryl groups and animal lipids would explain its accumulation in living organisms, particularly in lipid tissue of mammals. Figures 7 and 8 show the chromatograms from a fish muscle tissue (Cysnoscion Maracaiboensis) and mussels (Polymesoda solida) from Lake Maracaibo, determined with the proposed method. In the fish muscle tissue, only methylmercury was found $\left(25.1 \mu \mathrm{g} \mathrm{Kg}^{-1}\right)$. Previous investigations by Westoö (33) found that mercury in fish is mainly in the form of methylmercury, as is also the case for other types of aquatic organisms. The value found in Lake Maracaibo is low compared with data from Lake Mississippi (USA), where the concentration ranged from $0.634 \mathrm{mg} \mathrm{Kg}^{-1} \mathrm{Hg}$ to $1.89 \mathrm{mg} \mathrm{Kg}^{-1} \mathrm{Hg}$ (34).

The mussel samples (Polymesoda solida) showed both species, methylmercury (mean: $101 \mu \mathrm{g} \mathrm{Kg}^{-1}$ ) and inorganic mercury (mean: $73.4 \mu \mathrm{g} \mathrm{Kg}^{-1}$ ). The mean of the total mercury concentration in this sample was $178.0 \mu \mathrm{g} \mathrm{Kg}^{-1}$. The total value is similar to the values found in estuaries (35) and in oysters from 


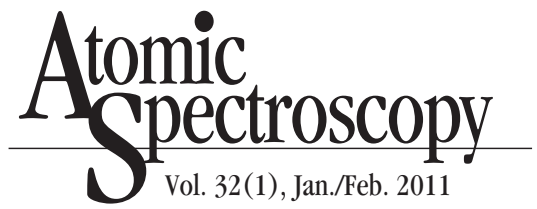

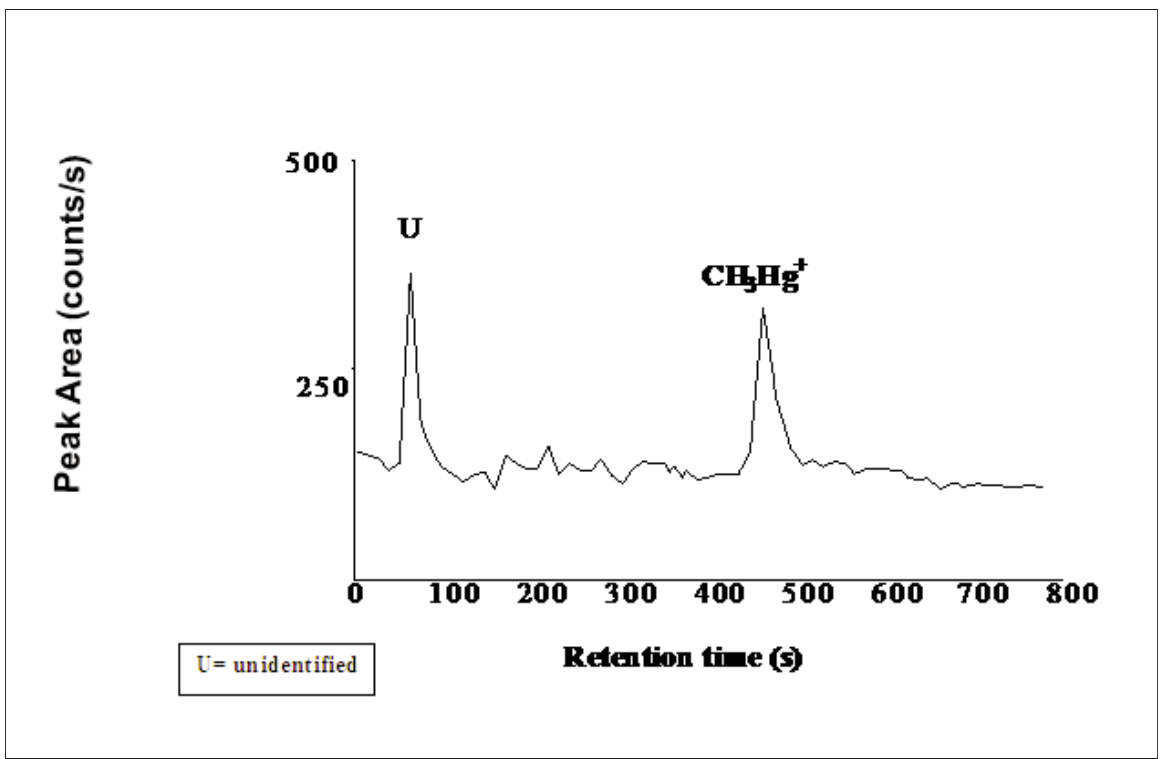

Fig. 7. Chromatogram of a sample of fish muscle tissue (Curvina, Cysnoscion Maracaiboencis) from Lake Maracaibo using the proposed method for the determination of mercury species.

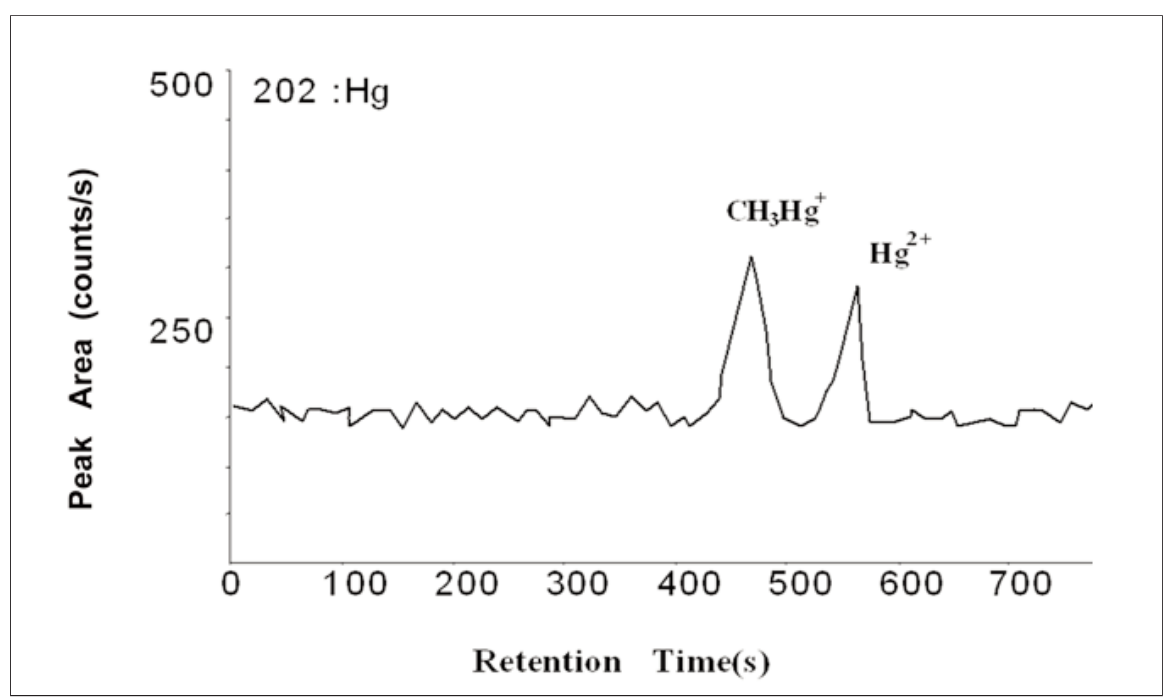

Fig. 8. Chromatogram of a mussel sample (Polymesoda solid) from Lake Maracaibo.

Cartagena Bay (Colombia) where a chlor-alkali plant is located (36).

\section{Principal Components Analysis}

The purpose of the analysis is to obtain a small number of linear combinations of the 10 variables which account for most of the variability in the data (39). In this case, the variables taken into account were nitrogen, phosphorus, sulfur, methylmercury, inorganic mercury, total mercury, depth, dissolved oxygen, $\mathrm{pH}$ and salinity, at 13 sampling points.

Four components have been extracted since 1888 with eigenvalues greater than or equal to 1.0. Together they account for $88.9 \%$ of the variability in the original data. The variables taken into account at 13 sampling sites were: Nitrogen, phosphorus, sulfur, methylmercury, inorganic mercury, total mercury, depth, dissolved oxygen, $\mathrm{pH}$, and salinity. Table VIII shows the eigenvalues; there are four components that control $88.9 \%$ of the variability of the data. The parameters that affect most of these components are methylmercury, total mercury, salinity, sulfur, and depth. Figure 9 shows the parameters that have more influence on the variability of the data. The relatively high eigenvalues for components 1 and 2 of the principal component analysis showed that salinity, methylmercury, and total mercury affected all of the results in the Lake Maracaibo system. This can be explained because the Lake Maracaibo system consists of an estuary, a strait, and the lake. In these three ecosystems, salinity variations can affect the distribution of methylmercury and inorganic mercury. Also, the depth and sulfur concentrations in general can contribute to the variation of data for component 1 , but are affecting component 2 values negatively (see Figure 9).

The results found in Table VII can be explained because methylmercury increases with the sulfur concentration under certain conditions that are affected by the dissolved oxygen concentration and the $\mathrm{pH}$.

In general, the results from Lake Maracaibo show accumulation of the methylmercury species in sediment and biological materials.

There is evidence of some methylation of the inorganic mercury in the center of the Lake. Certain sulfur species appear to influence the methylation of mercury in the sediments. 
TABLE VIII

Eigenvalues Obatined From Principal Components Analysis

\begin{tabular}{cccc}
\hline Number & Eigenvalue & Variance & Percentage \\
\hline 1 & 4.543 & 45.4 & 45.4 \\
2 & 1.838 & 18.4 & 63.8 \\
3 & 1.449 & 14.5 & 78.3 \\
4 & 1.058 & 10.6 & 88.9 \\
5 & 0.526 & 5.3 & 94.2 \\
6 & 0.303 & 3.0 & 97.2 \\
7 & 0.215 & 2.2 & 99.3 \\
8 & 0.052 & 0.5 & 99.8 \\
9 & 0.014 & 0.1 & 99.9 \\
10 & 0.004 & 0.1 & 100.0 \\
\hline
\end{tabular}

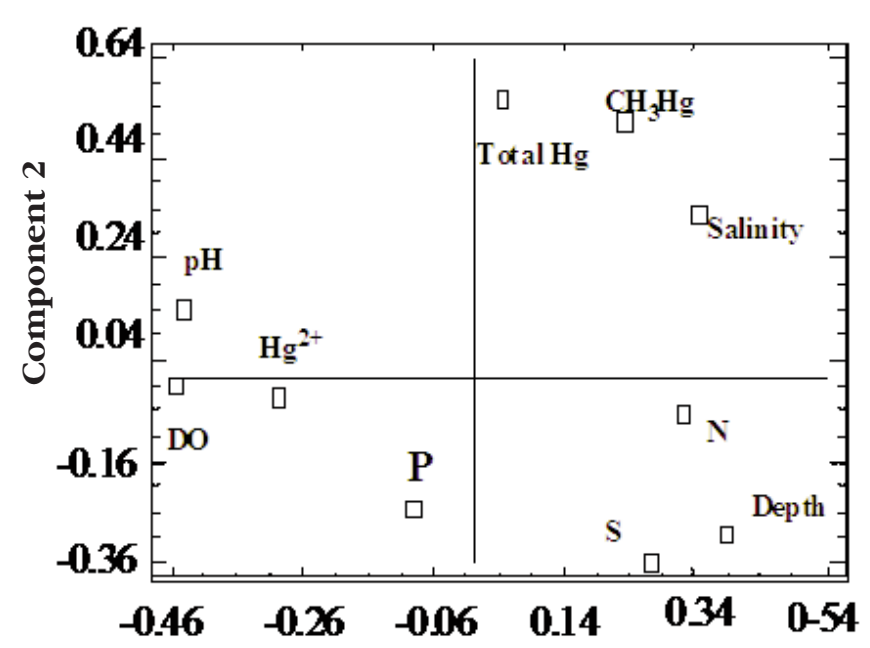

Component 1

Fig. 9. Plot of the component weightings of the parameters for the principal components 1 and 2 that produce more variability of the data.

\section{CONCLUSION}

The proposed method for the determination of mercury species is useful in the analysis of environmental samples such as sediments, fish, and mussels. The results from Lake Maracaibo show accumulation of the methylmercury species in sediments and biological materials.

There is also evidence of some methylation of the inorganic mercury in the center of the Lake.

\section{REFERENCES}

1. M. Colina and R. Romero, Analyst 17, 645 (1992).

2. M.E. Crespo-Lopez, G.L. Macedo, S.I.D. Pereira, G.P.F. Arrifano, D.L.W. Picano-Diniz, J.L.M. do Nascimento, and A.M. Herculano, Pharm. Res. 60(4), 212 (2009).

3. W.F. Fitzgerald, C.H. Lamborg, and C.R. Hammerschmidt, Chem. Rev. 107, 641 (2007).

4. T. Peretyazhko,; L. Charlet, B. Muresan, B. V. Kazimirov. and D. Cossa Sci. Total Environ. 364, 260(2006)

5. A. Bouffard and M. Amyot, Chemosphere 74, 1098 (2009).

6. M. Dipasquale, M. Lutz, M. Brigham, D. Krabbenhoft, G. Aiken, W. Orem, and B. Hall, Environ Sci. Technol. 43, 2726 (2009).

7. B. Muresan, D. Cossa, S. Richard, and B. Burban, Sci. Total Environ. 385, 132 (2007).

8. C. Beucher, P. Wong-Wah-Chung, C. Richard, G. Mailhot, M. Bolte, and D. Cossa, Sci. Total Environ. 290, 131 (2002).

9. E. Garcia, M. Amyot, and P. Ariya, Geochimica et Cosmochimica Acta 69, 1917 (2005).

10. L.Fantozzi, R. Ferrara, F. Frontini, and F. Dinis, Sci. Total Environ. 407, 917 (2009).

11. H. Zhang and S. Lindberg, Environ. Sci. Technol. 35(5), 928(2001).

12. M. Amyot. G. Gill, and F. Morel, Environ. Sci. Technol. 31, 3606 (1997).

13. N. O'Driscoll, S. Siciliano, and D. Lean, Sci. Total Environ. 304, 285 (2003).

14. C. Dill, T. Kuiken, H. Zhang, and M. Ensor, Sci. Total Environ. 357, 176 (2006).

15. S. Siciliano, N. O'Driscoll, and D. Lean, Environ. Sci. Technol. 36, 3064 (2002).

16. H. Wiatrowski, P. Ward, and T. Barkay, Environ. Sci. Technol. 40, 6690 (2006).

17. A. Poulain, M. Amyot, D. Findlay, S. Tel-or, T. Barkay, and H. Hintelmann, Limnol. Oceanogr. 49, 2265 (2004). 


\section{Atomic $_{\text {Spectroscopy }}^{\text {to }}$ \\ 1 Vol. 32(1), Jan./Feb. 2011}

18. V. St Louis, J. Rudd, C. Kelly, R. Bodaly, M. Paterson, K. Beaty, R. Hesslein, A. Heyes, and A. Majewski, Environ. Sci. Technol. 38, 1348 (2004).

19. S. Siciliano, N. O'Driscoll, R. Tordon, J. Hill, S. Beauchamp, and D. Lean, Environ. Sci. Technol. 39, 1071 (2005).

20. G. Parra-Pardi, J. Great Lakes Res. 9, 439 (1983).

21. J.Stimson and S. Larned, J. Exp. Mar. Biol. Ecol. 252, 159 (2000).

22. R.Carman, E. Gunnard, and Ch. Damberg, Chemical Geology 163, 101 (2000).

23. J.Drabowicz. Sulphur in Elemental Determination. Encyclopedia of Earth System Science London, UK, p. 4824 (1999).

24. J. Mawhinney, Determination of Trace Elements in Hair for Monitoring Environmental and Occupational Exposure, PhD Thesis, Sheffield Hallam University, UK., p. 198 (2000).

25. M. Colina and P. Gardiner, J. Chromatogr. A 847, 285 ( 1999).

26. P.Goulden, B. Afghan, An Automated Method for Determining Mercury in Water, Technical Bulletin No. 27, in Land Waters Branch Department of Energy, Mines and Resourses, Ottawa, Canada (1970).

27. J. Suda, M. Suda, and K. Hirayama, Arch. Toxicol. 67, 365 (1993).

28. J. Matschullat, R. Perobelli, E. Deschamps, B. Ribeiro, T. Gabrio, and M. Schwenk, Applied Geochem. 15, 193 (2000).

29. M. Horvat, L. Liang, Anal. Chim. Acta 282, 135 (1993).

30. D. Cossa, J. Sanjuan, J. Cloud, P. Stockwell, and W. Toms, J. Anal. At. Spectrom. 10, 287 (1995) .

31. R. Cela, R. Lorenzo, E. Rudi, A. Botana, M. Valino, C. Casals, M.Garcia, M. Mejuto, and M. Bollain, Environ. Technol. 13, 11 (1992).

32. U. Förstner and G. Witmann, Metal Pollution in the Aquatic Environment, Springer-Verlag, Berlin, Germany, p.17 (1979).
33. R. Hartung, In: Metal Pollution in the Aquatic Environment, Springer -Verlag, Berlin, Germany, p.18 (1979).

34. H. Bootsma, P. Lavrentyev, and F. Troncone, Limnol. Oceanogr. 43(8), 1814 (2001).

35. J. Matschullat, R. Perobelli, E. Deschamps, B. Ribeiro, T Gabrio, and M. Schwenk, Appied Geochem. 15. 193 (2000).

36. D. Huggett, J. Steevens, J. Allgood, C. Lutken, C. Grace, and W. Benson, Chemosphere 42,923 (2001).

37. J. Morse, B. Presley, R. Taylor, G. Benoit, and P. Santschi, Mar. Environ. Chem. 36, 1 (1993).

38. D. Alonso, P. Pineda, J. Olivero, H. González, and N. Campos, Environ. Pollut. 109, 157 (2000).

39. J. Miller and J. Miller, Statistcs for Analytical Chemistry, 3rd Edition, Ellis Horwood PTR, Prentice Hall,Chichester, West Sussex, England (1993). 